Dr. J.A. Kuperus

THE DUTCH SYSTEM OF FARM CLASSIFICATION

Mededelingen en Overdrukken
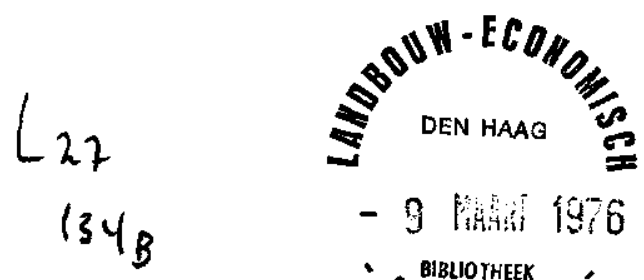

- 31940196

No. 134

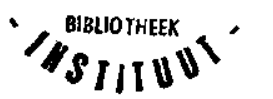

Verschenen in European Review of Agricultural Economics $2(1974 / 1975) 1: 47-64$ 


\title{
The Dutch system of farm classification
}

\author{
JAN AGE KUPERUS \\ Landbouw-Economisch Instituut, The Hague
}

\section{Summary}

After a discussion of the basic principles of the Dutch type of farming classification, a brief description of the system at each of the various stages is given. The method is applied to a random sample of Dutch farms, and the results are compared with those of the EEC and German systems applied to the same sample. The basic principles and the detailed application of the three systems are compared and discussed.

\section{Introduction}

The present system of farm classification originated in 1961 in an article dealing with the problem of defining a specialized horticultural holding and distinguishing it from a farm growing only some horticultural products (Wely, 1961). In this article the basic principles of the present system were developed, and since then only minor alterations have been introduced.

Before 1961 farm classification was based solely on the use of land as grassland, arable land or land for horticulture. In general, four types of farming were distinguished in a very rough way, namely, three types of agricultural holdings - grassland or dairy farms, arable and mixed farms - and, as a fourth category, horticultural holdings. Mixed farms in this classification were farms with both grass and arable land; in many cases combined with pig and egg production. A further distinction was sometimes made between mixed farming on sandy soils, where arable products are mainly used as feed on the farm, and mixed farms on clay and peat soils where as a rule the arable products are sold and livestock production is based on grass only.

The present article first describes the basic principles of the Dutch system of farm classification, then the steps which have subsequently been taken to refine the system and, finally, some comparisons of the results of different systems of classification when applied to farming in the Netnerlands. 


\section{Basic principles}

\subsection{General remarks}

The first principle of the Dutch scheme is that it is fundamentally an economic classification. Each farm is seen as an economic entity, as a business. The basis of the classification is essentially the economic value of a farm's production, and, for this purpose, a common measure for both crops and livestock has to be found.

Secondly, the system of classification is not based on the actual production of the farm, but on its standardized potential productive capacity, given the actual use of the available factors of production. For any particular year the standard production of a farm is therefore defined as the production which under specified average conditions could be achieved with the given stocking and cropping patterns of that farm. The production per unit of land and of livestock is standardized, and the actual numbers of livestock and the areas of each crop are multiplied by this standard production per unit to estimate the total 'standard production' of the farm.

Thirdly, the standard production is measured in units, and the total number of units indicates the size of the farm business.

Fourthly, the relative importance of the enterprises within a farm determines the type of farming category to which that farm is assigned.

\subsection{The basis of the classification}

According to the first principle mentioned in section 2.1, the classification should be based on the economic importance of the farm as a whole and of the various enterprises within it. The common unit for measuring both crops and livestock may be physical or monetary.

At the beginning of the fifties the physical unit widely used in farm management and socioeconomic research in the Netherlands was the number of hours of manual labisur required annually for each crop and for each class of livestock, expressed in terms of standard-man-hours (s.u.).

In 1958 a new yardstick was developed. This time it was a monetary one -- the total cost of work (labour, equipment, power, contract work) expressed in terms of work-units (b.e.). This change arose because of the declining importance of labour in relation to total cost of work as a result of increasing mechanization and other forms of substitution of capital for labour and with the increasing variation in the composition of these costs.

Moreover, experience had shown that the use of the word 'hour' in the term 'standard-man-hour' implied a connection with actual labour requirements, whereas the number of s.u. was related to labour requirements in the base period. This caused much misunderstanding in later years because, in the meantime, actual labour requirements had declined considerably. To avoid such misunderstanding a name unrelated to any physical 
measure was chosen. In fact, a work-unit (b.e.) corresponded to an amount of Dfl. 8. - of cost of work in the base period. Although, due to wage increases and rising costs of other items and despite improvements in productivity, actual costs were increasing, the b.e. was not changed.

A second change in the unit of measurement was made in 1968. The new yardstick was based on factor costs ${ }^{1}$ at 1968 prices, associated with efficient farm management, and was expressed as 'standard business units' (s.b.e.). A standard business unit was valued at Dfl. 200 .... factor costs in 1968 . The setting of this standard was related to the fact that in 1968 a farm with 100 s.b.e. per labour unit was considered to have a sufficient size of business to be viable. Here, too, the unit was chosen to avoid misunderstanding arising from the use of yardsticks with names reminiscent of physical units.

The system of classification has also been modified according to changing concepts in research. The Dutch publications on types of farming in 1962, 1965 and 1968 were based on labour units (man years of 2,500 s.u.). In 1968 data were also given on the basis of s.b.e., which were then accepted as the only basis for future classification (Wely, 1964, 1968; Centraal Bureau voor de Statistiek, 1971).

One other point must be mentioned here. Although, according to the first principle, the economic value of a farm's production should be the basis of classification, in fact costs of production are used. The expression 'economic value' is used to indicate that the relevant measure of production of a farm or part of a farm is not gross output but rather net product. The latter corresponds to net added value in the macroeconomic sense and includes the remuneration to the primary factors of production (land, labour and capital). Net profit, therefore, is a part of this added value.

For classification purposes, however, a stable set of coefficients based on long-term ratios between net products of the various crops and classes of livestock is needed. Because of sharp fluctuations in revenue due to variations in yields and prices, it is difficult to derive such a set from the actual levels of net output from the different farm enterprises. The total cost of production of the different crops and classes of livestock are much more stable over time. The factor costs incorporated in the total cost of production as measured on groups of farms with comparable levels of efficiency and mechanization have, therefore, been taken as the basis for classification. There was also the theoretical argument that in the long run the ratios between the levels of net product of the various farm enterprises will tend to equal the ratios between the levels of factor costs on efficient farms as a consequence of adjustments in supply and demand. In the long-run equilibrium there is no net profit as costs and revenues balance. 


\subsection{Use of uniform standardized coefficients}

In general farms can be classified using the simple data relating to acreages of crops and numbers of livestock on each farm at a certain date, since this is the kind of information that can be collected in an agricultural census or survey. However, since no data are available on the actual levels of factor cost or net product of each farm, the use of standardized coefficients is inevitable. These standards can only be rough approximations, but, if there are wide differences between regions or farms of different size, the coefficients can be adjusted accordingly.

In the Netherlands different regional coefficients are not used partly because of the relatively small regional variation and partly for convenience. Uniform coefficients facilitate the analysis of regional differences in farm type and in such ratios as s.b.e. per man and s.b.e. per hectare which can be used for comparative analysis of labour efficiency and intensity of land-use.

The same argument applies to farm size. Differences between farms of varying size can more easily be analysed by means of uniform coefficients than by coefficients which are adjusted $a$ priori on the basis of size.

Furthermore, under the Dutch system the coefficients are not adjusted each year but kept constant over time. This is of real practical value in analysing developments in farm structure and size.

If farm account data are available, the total number of s.b.e. on a farm, taken as a standard measure of its potential net production, can be set against the actual levels of net production and factor costs and be used for further comparative analysis.

Classification is not an end in itself but has to serve the purposes of providing a more accurate description of the farm sector and of offering a wider scope for research. In this respect it is an advantage to have a connection between the basis of classification and the ratios used for determining farm size, labour efficiency and intensity of land-use and to apply uniform coefficients for different regions and years.

If there are large differences in the relative levels of net product or factor costs for the various farming activities between regions or groups of farms (by size or type), there might well be a need for separate coefficients. Similarly, adjustment might be needed to take account of changes in the relative levels of net product or factor income over time. If, however, there are only proportionate changes in these levels the need is not so great, since they can be accounted for by applying the appropriate factors for different years, regions or farming groups to the existing coefficients. The relative shares of the various farming activities in total production are not affected, and a uniform basis for the classification can be maintained.

Since each region or each farm will, according to the principle of comparative advantage, tend to specialize in the most profitable activities and, moreover, since it is desirable that the coefficients themselves be based on long-term trends, there will probably be no great need for regional differentiation. If they should be necessary, a 
satisfactory solution could be found in applying regional factors or by making further sub-divisions into farm activities according to the production technique employed. For example, a distinction might be made between extensive and intensive fruit and vine production.

There is a real practical advantage to be gained by using a uniform set of coefficients which should only be given up if there is a strong need to do so.

\subsection{Size of business}

According to the third principle, as stated in 2.1, size of business in the Dutch system is measured in the same units as are used for the type-of-farming classification. The main table in all statistical publications based on this classification contains the number of farms in each type and in each size class, both based on the same units of measurement.

In the earlier system, based on standard-man-hours, size of business was expressed in standard-man-years of 2,500 hours, but now the total number of standard work units (s.b.e.) is used.

For some purposes, such as the presentation of farm revenues, the class limits are shifted upwards annually to take account of increases in the scale of farming and labour productivity. This is shown in Table $1 .^{2}$

Table 1. Lower limits of size classes (in s.b.e.)

\begin{tabular}{llllllll}
\hline & \multicolumn{1}{c}{ Small farns } & \multicolumn{2}{c}{ Large farms } & & & \\
\hline 1968 & 30 & 70 & 90 & 130 & 170 & 210 & 250 \\
1969 & 33 & 73 & 93 & 133 & 173 & 213 & 253 \\
1970 & 38 & 78 & 98 & 138 & 178 & 218 & 258 \\
1971 & 43 & 83 & 103 & 143 & 183 & 223 & 263 \\
1972 & 48 & 88 & 108 & 148 & 188 & 228 & 268 \\
1973 & 53 & 93 & 113 & 153 & 193 & 233 & 273 \\
\hline
\end{tabular}

\section{Application of the type-of-farming classification}

\subsection{Definition of a farm and its activities}

The starting point in applying a complete type-of-farming schedule is the specification of the various farming activities to be used in the classification. As any national classification has to apply to national circumstances, neither forestry nor the growing of olives or viticulture are considered as farming activities in the Netherlands.

2. It would have been better if the relative increase had been the same for all limits. From 1968 to 1973 , the relative increases varied from
$9 \%$ for farms in the largest size group to $77 \%$ for farms in the smallest size group. 
In the Dutch system there are three stages of farm-type: sectors, sections and enterprises. There are a'so three farming sectors, namely, livestock production (Veehouderij), arable production (Akkerbouw) and horticulture (Tuinbouw). Using the initial letters of the Dutch words, the system is called the $V A T$ system.

The livestock sector includes not only cattle, sheep, horses, pigs and poultry but also the use of grassland. The arable sector includes all crops except horticultural crops, cultivated under glass or in the open air. Some crops like onions and peas for industrial processing are considered as horticultural even if they are grown extensively. It is expected, however, that at the next revision the definition of arable crops will be amended to include all crops grown extensively. For the purposes of continuity the division between arable production and horticulture was maintained in the revisions of 1968 and 1971.

Two of these three farming sectors are subdivided into sections. Livestock has three sections, namely, cattle production including veal, pig and poultry production. Horticulture also has three sections, which are cultivation under glass, outdoor rotational and perennial crops.

Within these sections and within the arable sector a further sub-division is made into enterprises, in which a particular farm may specialize.

\subsection{Definition of type of faming}

The definition of type of farming closely follows the division of the farming activities into sectors, sections and enterprises. Consequently three stages are used:

1. sector farm type

2. section farm type

3. enterprise farm type

A subsequent stage provides for a further subdivision so that a sector type can be subdivided into section types and a section type into enterprise types. A survey of the Dutch schedule is given in Table 2.

At the three stages three categories of farm type are distinguished: ${ }^{3}$

a) Specialized farms (S) in which one sector (or section or enterprise) is predominant and the others are of relatively small importance.

b) Mixed farms (M) in which two or all three sectors or sections are of more or less equal importance. These mixed farms are subdivided at the enterprise stage according to the combination of sectors or sections and their order of importance.

c) Other farms (O) which (i) have a combination of sections (or enterprises) and therefore cannot be considered as specialized farms at the section (or enterprise) stage

3. The letters (O), (M) and (S) indicating the categonies of farm types refer to the schedule of Table 2, and the figures in the right hand column of Table 2 refer to the enterprise farm types. 
Table 2. Review of the Dutch type-of-farming classification, 1971/ $S=$ specialized types, $M=$ mixed types, $O=$ other types)

Sector farm type Section farm type

Cattle (S)

Livestock (S)

Pig (S)

Poultry (S)

Other livestock $(0)$

Arable (S)

Arable (S)

Horticultural (S) Cropping under glass (S)

Crops in the open (S)

Permanent crops (S)

Other horticultural (O)

Mixed (M)

Mixed (M)
Enterprise farm type

Dairy (S)

1. Specialist dairy $(80-100 \%)$

2. Other dairy $(60-80 \%)$

Beef production (S)

3. Calf fattening $(S)$

4. Other beef production $(O)$

5. Other cattle $(\mathrm{O})$

6. Pork production (S)

7. Pig breeding ( $\mathrm{S}$ )

8. Other pig (O)

9. Broilers ( $\mathrm{S}$ )

10. Layers (S)

11. Ducks (S)

12. Turkeys (S)

13. Other poultry $(\mathrm{O})$

14. Sheep (S)

15. Grassland (S)

16. Cattle/pigs (M)

17. Other livestock $(O)$

18. Cereals (S)

19. Potatoes and sugarbeet (S)

20. Cereal/potatoes and sugarbeet (M)

21. Other arable $(O)$

22. Vegetables under glass (S)

23. Flowers under glass (S)

24 . Other ctops under glass $(O)$

25 . Vegetables in the open (S)

26. Bulbs (S)

27. Other crops in the open $(0)$

28. Fruit (S)

29. Arboriculture (S)

30. Other permanent crops $(O)$

31. Vegetables under glass/in the open (M)

32. Mushrooms (S)

33. Other horticultural crops $(0)$

34. Livestock/arable (M)

35. Livestock/horticultural (M)

36. Arable/horticultural (M)

37. Livestock/arable/horticultural (M) 
or which (ii) specialize in a farming activity falling outside one of the sections (or enterprises) distinguished in the schedule.

With regard to (i) a specialized pig farm (section type) which combines breeding and fattening will be considered as an 'other pig farm' (8) at the enterprise stage. It is neither a pork production farm (6) nor a pig breeding farm (7). ${ }^{4}$

As an example of (ii), a sheep farm (14) at the enterprise stage will be assigned to the type 'other livestock farms' at the section stage for it is not a cattle, pig or poultry farm. A stud farm, which is not a common phenomenon in the Netherlands and can hardly be considered an agricultural business, will be assigned to the type 'other livestock farms' at both the section and the enterprise stage. It would, of course, have been possible to develop a more detailed schedule including horses as a separate enterprise and stud farms as a farm type at the enterprise stage.

There is one further point which deserves comment. Veal production is included in cattle production although, being based on purchased feed (milk products) and not on forage crops or grassland, it has more in common with pig or poultry production. This is done to maintain continuity since 1962 in the composition of the sector groups. However, it would probably be better to consider veal production as a separate section of the livestock category like poultry or pigs instead of including it in cattle production.

\subsection{Class divisions}

A general principle in classification is that each farm should be allotted to one, and only one, type-of-farming group. A point of practical importance is that the name given to the group should describe the actual situation on the farms belonging to it. It is difficult to introduce a system in which the farmer does not recognize his own farm. Experience will show to what degree the latter objective has been achieved under the Dutch system.

In 2.1 it was stated that the relative importance of the various farm activities within a farm must determine the type of farming group to which it is assigned. In practice this means that it is necessary to calculate:

a) the number of s.b.e. for each enterprise by multiplying actual crop acreages and numbers of livestock by the appropriate coefficients;

b) the total number of s.b.e. per farm (i.e., the size of business); and

c) the percentage share of each enterprise, section and sector in the total number of s.b.e. On the basis of these percentages the type of farming at the three different stages is determined. In the Dutch system a farm is termed specialized if at least $60 \%$ of its total s.b.e. come from one sector, section or enterprise. A mixed farm is one in which two or three sectors or sections each contribute from $20 \%$ to $60 \%$ of total s.b.e. From the very beginning the limits of $60 \%$ and $20 \%$ have been used. It is clear that they are somewhat

4. At the sector and section stages such a farm would be considered as a mixed farm. 'Other farms' therefore contain mixed farms (at the enterprise stage) and farms with a specialization not accounted for in the classification. 
arbitrary. Obviously, to be called a specialized farm, at least $50 \%$ of the s.b.e. must be accounted for by one activity but the lower limit has been set at $60 \%$ to avoid too ready a use of the term 'specialized farm'.

Although some authors defend the point of view that boundaries should be drawn through areas in the classification where only a few observations are to be found, in practice arguments of continuity and comparability over time and across regions have prevailed in maintaining these arbitrarily standardized limits. (In 4.1 the results of an experiment with alternative limits are discussed.)

On the basis of the calculated percentages and these limits of $60 \%$ and $20 \%$, each farm is assigned to one of the types of farming at each stage in the classification. A complication arises due to the fact that s.b.e. are calculated both for grazing animals and for grassland. If a farm has at least $60 \%$ of its s.b.e. in grassland then the farm is assigned to a specialized farm group, namely, grassland farms - enterprise farm type 15. If not, the s.b.e. for grassland are divided between cattle, horses and sheep, and a further classification is based on the total amount of s.b.e. for each of these livestock classes including their share in the grassland s.b.e.

\section{Comparison of different classification systems}

\subsection{Variation of limits within the Dutch system}

At each revision in 1965, 1968 and 1971, a decision has been taken on the lower limit for specialized farms at each classification stage. Until now, the limit has been kept at $60 \%$, but experiments with other limits have been made to see what effects such changes would have.

Appendix 1 shows the outcome of such an experiment on a random sample of about 13,000 out of the population of 169,122 farms in the 1973 Agricultural Census. The first column gives the number of farms in each enterprise-farm-type with the present limits at least $60 \%$ for the specialized farms and $20-60 \%$ for the mixed farms. Three alternatives are also calculated - limits of 16.7 and $66.7 \%$ (column 2), 12,5 and $75 \%$ (column 3), and 5 and $90 \%$ (column 4). It is obvious that by raising the lower limit for specialized farms, the number of mixed farms will be increased. In the last alternative a mixed farm is a farm with two or more activities having each $5-90 \%$ of its s.b.e. and such a type will contain very heterogeneous farms.

The data in Appendix 1 are summarized in Table 3 for the sector farm-types.

In interpreting the data shown in Table 3 and Appendix 1, it should be borne in mind that the same limits have different meanings for different types of farming. The crop rotation requirements in arable farming impose technical limits on specialization which are not present in other types of farming. This could be an argument for differentiation of limits within a system. Until now, however, simplicity has been an overriding consideration. 
Table 3. Altemative limits in the Dutch type-of-farming classification (1973)

\begin{tabular}{llccc}
\hline Specialized farms & $\geqslant 60 \%$ & $\geqslant 66.7 \%$ & $\geqslant 75 \%$ & $\geqslant 90 \%$ \\
Mixed farms & $20-60 \%$ & $16.7-66.7 \%$ & $12.5-75 \%$ & $5-90 \%$ \\
\hline Livestock & $(1)$ & $(2)$ & $(3)$ & $(4)$ \\
Arable & 109889 & 106453 & 101354 & 84519 \\
Horticultural & 14189 & 12386 & 10553 & 7294 \\
Mixed & 34088 & 32886 & 31525 & 28516 \\
\hline Total farms & 10956 & 17397 & 25688 & 48793 \\
\hline
\end{tabular}

Inspection of the number of specialized farms at sector stage (Table 3) reveals that when the lower limit is moved from $60 \%$ to $90 \%$, no fewer than $77 \%$ of the livestock farms, $51 \%$ of the arable and $83 \%$ of the horticultural holdings remain specialized.

These percentages illustrate the high degree of specialization in Dutch agriculture. Figure 1 gives a more detailed view of this phenomenon. The distribution of all farms according to the contribution of livestock and arable to the total s.b.e. of the farm is indicated on the basis of the 1973 sample. Every dot represents at least 100 farms in a square and if there are more than 500 farms in any square the number itself is given. Blank squares indicate that both in 1971 and in 1973 there were fewer than 100 farms in a square. A cross in a square indicates that there were at least 100 farms in a square in 1971 but none in 1973.

It follows from Figure 1 that nearly all Dutch farms are in the periphery of the diagram, which means that within any farm only one or two sectors are important. The number of farms in the range $60 \%$ to $75 \%$ of one sector is very small. In particular the crosses show that between 1971 and 1973 the number of farms with $50 \%$ to $70 \%$ livestock farming declined.

Since under Dutch conditions it makes little difference whether the limit is put at $60 \%$ or at $75 \%$, it was decided to maintain the $60 \%$ limit. This conclusion, of course, would not necessarily apply to other countries.

\subsection{Comparison of the Dutch and German classification systems}

Three of the four general principles of the Dutch model, as described in 1.1, have been adopted in the recent German classification system (Deselaers, 1971, 1974). They are an economic basis, standardized coefficients and the relative importance of activities deter. mines the type of farming. But a different method is adopted for the size of business classification. There are some differences of detail in the type of farming classification:

a. the German grouping is based on potential gross margin (Standarddeckungsbeitrag);

b. the three sectors are agriculture, horticulture and forestry; 
Figure 1. Dutch farms 1973

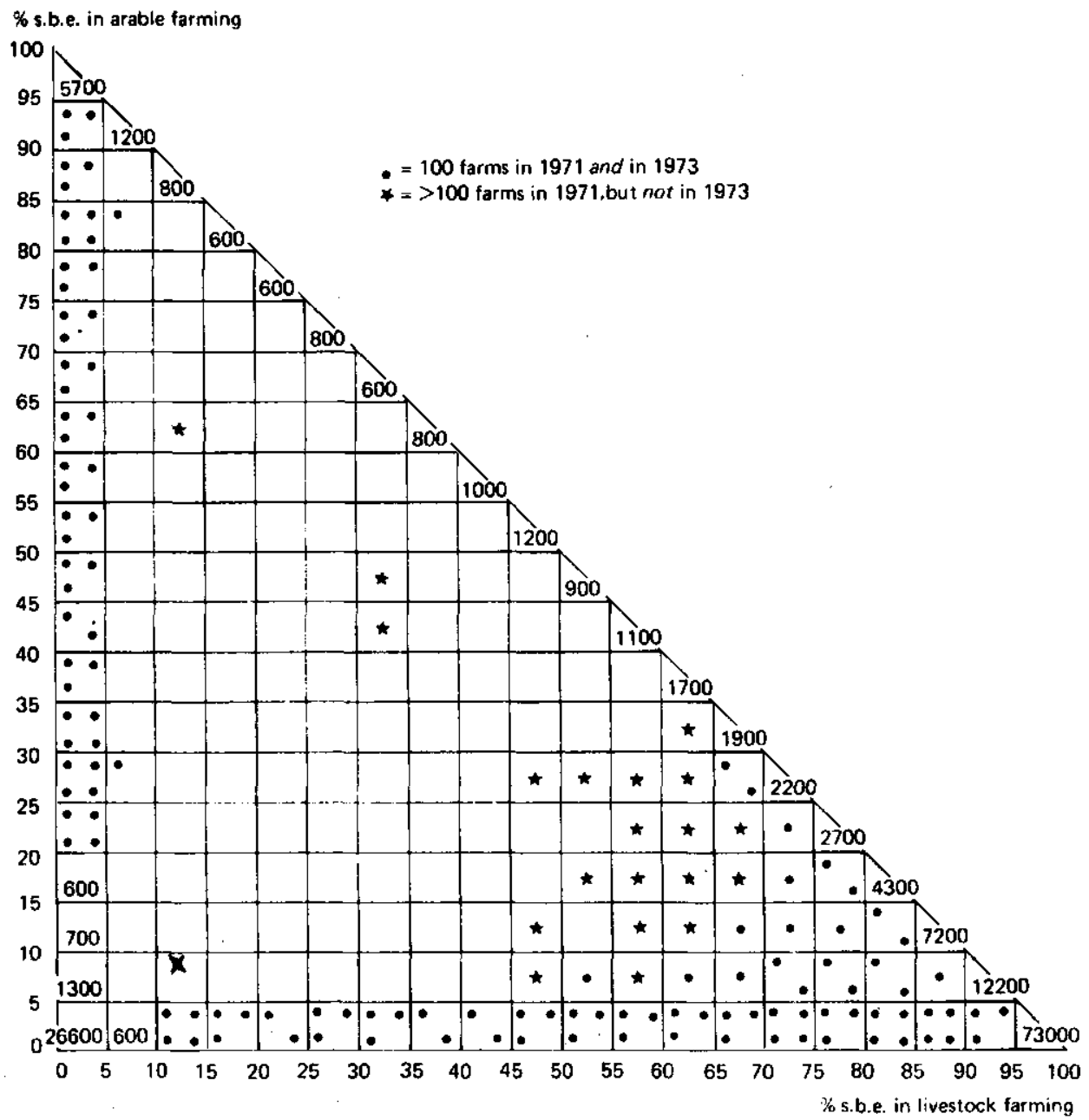

c. a farm is specialized at farm sector stage if one sector provides at least $75 \%$ of its potential gross margin;

d. a farm is specialized at farm section stage if one section produces at least $50 \%$ of its potential gross margin;

e. at the farm enterprise stage a farm is assigned to a specialized enterprise type if the enterprise has the largest share in the farm's potential gross margin. 
To compare the results of the two systems, the German method is applied to the sample of Dutch farms mentioned above. Appendix 2 indicates the distribution of Dutch farms according to the Dutch and German type-of-farming classifications.

Some arbitrary decisions were inevitable in incorporating each activity in an enterprise, and forestry could not be included.

From Appendix 2 it must be concluded that despite the differences mentioned above and the use of different coefficients in each, the outcomes of applying both systems are very similar.

The size of business in the German classification system is not based on potential gross margin, as in farm-type, but on potential farm income. To obtain this potential farm income a standardized amount of allocated fixed costs of production and of farm overhead are deducted from the potential gross margin. This standardized amount varies according to type of farming and size of business.

The deduction is made because the German system aims at an estimate of the average level of potential income in DM for larger groups of farms and for regions taking into account scale effects. The Dutch system avoids such complications by using a measure of farm size, which is a linear combination of the numbers of technical units (acres or animals) of the various activities which is not expressed in monetary terms or does not bear any relationship to monetary values. In the Dutch system the opposite method is followed. The ratio of actual income per s.b.e. as derived from farm account data can be used to analyse variations in income connected with farm size, farm type or region and income trends over time.

A major difficulty with the German system is that, due to price movements, the actual levels of income in future years are bound to outrun the estimates so that revision will be necessary to avoid misunderstanding by inexperienced users. As mentioned above, in our experience it is a great advantage to be able to use the same coefficients in subsequent years as long as there is no great need for adjustment to changes in the pattern of potential income capacity of the various crop and livestock products.

\subsection{Comparison of the Dutch and EEC classification systems}

The EEC system which is being revised in 1975 has until now adopted the same three general principles as the German classification system (European Commission, 1966).

The important differences in the type-of-farming classification are:

a. its base is the gross output of the farm and its activities;

b. four sectors are distinguished: arable farming, permanent crop production, 'livestock farming dependent on land' and 'livestock farming independent of land';

c. a farm is specialized at the sector stage if at least two-thirds of the farm's output comes from the corresponding sector;

d. a farm is specialized at the section or enterprise stage if at least $50 \%$ of total farm output comes from the corresponding section or enterprise. 
The results of the Dutch and the EEC classifications are compared in Appendix 3, which gives the number of farms in each Dutch farm-type classified according to the EEC system.

Appendix 3, too, leads to the conclusion that in many cases there is a close similarity between the two methods. There is, however, one major exception. Pig breeding farms under the EEC definition (farm type 448) are spread over a wide range of farm types in the Dutch system. This is caused by the difference in the basis of classification - gross output (EEC) or factor costs (Netherlands) - which leads in the author's view to an overestimation in the EEC system of the economic importance of pig and other livestock farming based on purchased feedingstuffs.

\subsection{Possibilities of extending the Dutch system}

The Dutch system, as described and compared in the preceding paragraphs, is used for all general statistical purposes. It is used for comparisons at several stages: sector farm type (more or less comparable since 1962), section farm type and enterprise farm type. Further research may lead to other developments. It is also likely that the adoption of a new EEC classification in the future will have implications for the Dutch system. For special purposes a specific classification may be necessary, based on simple physical relationships without financial evaluation.

An example of a recent case study may illustrate these possibilities. In preparing an investigation into arable farming within the general Dutch type-of-farming classification, it seemed desirable to have some idea of the main differences between the larger farms of this type in various regions. After a number of experiments it appeared that a very simple type classification on the basis of the acreage distribution of crops gave a good picture of these differences.

The type-of-farming groups are as follows:

a. the acreage is divided into four kinds of crop: cereals, potatoes, sugarbeets and other rotation crops;

b. farms with at least $60 \%$ in other rotation crops are excluded;

c. farms with at least $15 \%$ of potatoes are divided into three types, where the kind of potatoes with the largest acreage defines the type:

I : Industrial potatoes

II : Seed potatoes

III : Other potatoes (in general, potatoes for human consumption).

d. farms with less than $15 \%$ of potatoes form type IV, which could be indicated as cereal farms.

Some data about these four types of arable farms are presented in Table 4.

From this simple classification it will be seen that the potato crops for different uses can be apportioned almost exclusively to different farm types. It is a matter for further research to examine whether or not these types, then based on s.b.e., would give a better classification of arable farms than the present enterprise farm types 18-21. 
Table 4. Types of Dutch arable farms (Agricultural Census 1973)

\begin{tabular}{|c|c|c|c|c|c|c|c|c|}
\hline \multirow[t]{2}{*}{ Туре } & & \multirow{2}{*}{$\begin{array}{l}\text { Number } \\
\text { of farms }\end{array}$} & \multicolumn{4}{|c|}{ Percentuges of total acreage in: } & \multirow[b]{2}{*}{$\begin{array}{l}\text { Sugar- } \\
\text { beets }\end{array}$} & \multirow[b]{2}{*}{$\begin{array}{l}\text { Other } \\
\text { crops }\end{array}$} \\
\hline & & & Cereals & $\begin{array}{l}\text { Industrial } \\
\text { potatoes }\end{array}$ & $\begin{array}{l}\text { Seed } \\
\text { potatoes }\end{array}$ & $\begin{array}{l}\text { Potatoes } \\
\text { for human } \\
\text { consump- } \\
\text { tion }\end{array}$ & & \\
\hline I: & $\begin{array}{l}\text { Industrial } \\
\text { potatoes }\end{array}$ & 3024 & 37 & 46 & - & - & 10 & 7 \\
\hline $\begin{array}{l}\text { II: } \\
\text { III: }\end{array}$ & $\begin{array}{l}\text { Seed pota- } \\
\text { toes } \\
\text { Potatoes for }\end{array}$ & 1278 & 31 & - & 26 & 3 & 24 & 16 \\
\hline IV. & sumption & 4027 & $\begin{array}{l}36 \\
47\end{array}$ & - & 1 & 24 & 24 & $\begin{array}{l}16 \\
27\end{array}$ \\
\hline Total & & & & & & $\ldots$. & & \\
\hline
\end{tabular}

\subsection{Conclusions}

The three systems of type-of-farming classification - the EEC, the German and the Dutch - all succeed in identifying the highly specialized farms in the Netherlands. Because of the relatively high weight attached to livestock production, based on purchased feedingstuffs, the EEC system is least successful in identifying farms with a high degree of specialization in this respect.

To achieve an effective classification of less-specialized farms, further research will be needed, particularly if the system has to cover a wider area with more divergent production patterns and farming structures.

The Dutch system differs from the German in that it applies the coefficients for calculating the economic importance of each branch of production without any adjustment in both type-of-farm and size-of-farm classifications. Furthermore, it uses as a measure of size a criterion which is not directly related to farm income.

These principles, it is claimed, are of considerable practical advantage for interpretation by inexperienced users and for use in further analysis. The EEC system which is based on gross revenue does not provide an adequate measure of farm size linked to type-of-farm classification. 
APPENDIX 1. Alternative limits in the Dutch type-of-farming classification

\begin{tabular}{|c|c|c|c|c|c|c|}
\hline & Specialization & Character & $\begin{array}{l}60 \% \\
\text { limit }\end{array}$ & $\begin{array}{l}66.7 \% \\
\text { limit }\end{array}$ & $\begin{array}{l}75 \% \\
\text { limit }\end{array}$ & $\begin{array}{l}90 \% \\
\text { limit }\end{array}$ \\
\hline \multirow[t]{2}{*}{$\begin{array}{l}1 . \\
2 . \\
3 . \\
4 . \\
5 .\end{array}$} & $\begin{array}{l}\text { Specialist dairy } \\
\text { Other dairy } \\
\text { Calf fattening } \\
\text { Other beef production } \\
\text { Other dairy production }\end{array}$ & $\begin{array}{l}\mathrm{S} \\
\mathrm{S} \\
\mathrm{S} \\
\mathrm{O} \\
\mathrm{O}\end{array}$ & $\begin{array}{r}49564 \\
24518 \\
1930 \\
2199 \\
2839\end{array}$ & $\begin{array}{r}49564 \\
17348 \\
1665 \\
1904 \\
3411\end{array}$ & $\begin{array}{r}49564 \\
6837 \\
1543 \\
1604 \\
3604\end{array}$ & $\begin{array}{l}36015 \\
- \\
1043 \\
1114 \\
2125\end{array}$ \\
\hline & Cotrle farms & $\mathrm{s}$ & 81050 & 73892 & 63152 & 40297 \\
\hline \multirow[t]{2}{*}{$\begin{array}{l}6 . \\
7 . \\
8 .\end{array}$} & $\begin{array}{l}\text { Pork production } \\
\text { Pig breeding } \\
\text { Other pig production }\end{array}$ & $\begin{array}{l}S \\
S \\
0\end{array}$ & $\begin{array}{l}3051 \\
3830 \\
1212\end{array}$ & $\begin{array}{l}2506 \\
2793 \\
1038\end{array}$ & $\begin{array}{l}2057 \\
2079 \\
1007\end{array}$ & $\begin{array}{r}1247 \\
881 \\
981\end{array}$ \\
\hline & Pig farms & $\mathbf{S}$ & 8093 & 6337 & 5143 & 3109 \\
\hline $\begin{array}{l}9 . \\
10 . \\
11 \\
12 . \\
13 .\end{array}$ & $\begin{array}{l}\text { Table poultry } \\
\text { Egg production } \\
\text { Ducks } \\
\text { Turkeys } \\
\text { Other poultry farms }\end{array}$ & $\begin{array}{l}S \\
S \\
S \\
S \\
O\end{array}$ & $\begin{array}{r}1025 \\
2124 \\
28 \\
131 \\
78\end{array}$ & $\begin{array}{r}908 \\
1877 \\
22 \\
131 \\
95\end{array}$ & $\begin{array}{r}857 \\
1566 \\
22 \\
104 \\
130\end{array}$ & $\begin{array}{r}564 \\
1184 \\
22 \\
83 \\
104\end{array}$ \\
\hline 13. & Poultry farms & $\mathbf{S}$ & 3386 & 3033 & 2679 & 1957 \\
\hline \multirow[t]{3}{*}{$\begin{array}{l}14 . \\
15 . \\
16 . \\
17 .\end{array}$} & $\begin{array}{l}\text { Sheep } \\
\text { Grassland } \\
\text { Cattle/pigs } \\
\text { Other livestock farms }\end{array}$ & $\begin{array}{l}\mathbf{S} \\
\mathbf{S} \\
\mathbf{M} \\
\mathbf{O}\end{array}$ & $\begin{array}{r}1004 \\
689 \\
10341 \\
5326\end{array}$ & $\begin{array}{r}760 \\
622 \\
15582 \\
6227\end{array}$ & $\begin{array}{r}650 \\
467 \\
21570 \\
7693\end{array}$ & $\begin{array}{r}411 \\
356 \\
26123 \\
12267\end{array}$ \\
\hline & Other livestock farms & 0 & 17360 & 23191 & 30380 & 39157 \\
\hline & Livestock farms & $\mathbf{S}$ & 109889 & 106453 & 101354 & 84519 \\
\hline \multirow[t]{2}{*}{$\begin{array}{l}18 . \\
19 . \\
20 . \\
21\end{array}$} & $\begin{array}{l}\text { Cereals } \\
\text { Potatoes and sugarbeets } \\
\text { Cereals/potatoes and sugarbcets } \\
\text { Other arable farms }\end{array}$ & $\begin{array}{l}S \\
S \\
M \\
O\end{array}$ & $\begin{array}{r}672 \\
5413 \\
3562 \\
4542\end{array}$ & $\begin{array}{r}345 \\
3514 \\
4867 \\
3660\end{array}$ & $\begin{array}{r}255 \\
1748 \\
5451 \\
3099\end{array}$ & $\begin{array}{r}188 \\
491 \\
4130 \\
2485\end{array}$ \\
\hline & Arable farms & $\mathbf{S}$ & 14189 & 12386 & 10553 & 7294 \\
\hline \multirow[t]{2}{*}{$\begin{array}{l}22 . \\
23 . \\
24\end{array}$} & $\begin{array}{l}\text { Vegetables under glass } \\
\text { Flowers under glass } \\
\text { Other crops L ider glass }\end{array}$ & $\begin{array}{l}\mathbf{S} \\
\mathbf{S} \\
\mathbf{O}\end{array}$ & $\begin{array}{r}6764 \\
5605 \\
808\end{array}$ & $\begin{array}{r}6357 \\
5352 \\
938\end{array}$ & $\begin{array}{l}5657 \\
4833 \\
1140\end{array}$ & $\begin{array}{l}3934 \\
3902 \\
1372\end{array}$ \\
\hline & Crops under glass & $\mathrm{S}$ & 13177 & 12647 & 11630 & 9208 \\
\hline \multirow[t]{2}{*}{$\begin{array}{l}25 \\
26 . \\
27 .\end{array}$} & $\begin{array}{l}\text { Vegetables in the open } \\
\text { Bulbs } \\
\text { Other crops in the open }\end{array}$ & $\begin{array}{l}\mathrm{S} \\
\mathrm{S} \\
\mathrm{O}\end{array}$ & $\begin{array}{l}4020 \\
4774 \\
1327\end{array}$ & $\begin{array}{l}3356 \\
4458 \\
1436\end{array}$ & $\begin{array}{l}2579 \\
4073 \\
1446\end{array}$ & $\begin{array}{l}1547 \\
3131 \\
1208\end{array}$ \\
\hline & Horticulture in the open & $\mathbf{S}$ & 10121 & 9250 & 8098 & 5886 \\
\hline \multirow[t]{2}{*}{$\begin{array}{l}28 . \\
29 . \\
30 .\end{array}$} & $\begin{array}{l}\text { Fruit } \\
\text { Arboriculture } \\
\text { Other permanent crops }\end{array}$ & $\begin{array}{l}S \\
S \\
O\end{array}$ & $\begin{array}{r}4117 \\
2180 \\
541\end{array}$ & $\begin{array}{r}3863 \\
2031 \\
461\end{array}$ & $\begin{array}{r}3511 \\
1902 \\
479\end{array}$ & $\begin{array}{r}2799 \\
1471 \\
403\end{array}$ \\
\hline & Permanent crop farms & $S$ & 6838 & 6355 & 5892 & 4673 \\
\hline \multirow[t]{3}{*}{$\begin{array}{l}31 . \\
32 . \\
33 .\end{array}$} & $\begin{array}{l}\text { Vegetables under glass/in the open } \\
\text { Mushrooms } \\
\text { Other horticulture }\end{array}$ & $\begin{array}{l}\mathrm{M} \\
\mathrm{S} \\
\mathrm{O}\end{array}$ & $\begin{array}{r}964 \\
897 \\
2091\end{array}$ & $\begin{array}{r}1363 \\
874 \\
2397\end{array}$ & $\begin{array}{r}1860 \\
862 \\
3183\end{array}$ & $\begin{array}{r}2740 \\
778 \\
5231\end{array}$ \\
\hline & Other horficulture & 0 & 3952 & 4634 & 5905 & 8749 \\
\hline & Horricultural holdings & & 34088 & 32886 & 31525 & 28516 \\
\hline $\begin{array}{l}34 . \\
35 \\
36 . \\
37 .\end{array}$ & $\begin{array}{l}\text { Livestock/arable } \\
\text { Livestock/horticulture } \\
\text { Arable/horticulture } \\
\text { Other mixed }\end{array}$ & $\begin{array}{l}M \\
M \\
M \\
O\end{array}$ & $\begin{array}{r}5727 \\
1979 \\
1891 \\
1359\end{array}$ & $\begin{array}{l}9175 \\
3111 \\
2861 \\
2250\end{array}$ & $\begin{array}{r}13758 \\
4270 \\
3879 \\
3781\end{array}$ & $\begin{array}{r}29625 \\
5070 \\
590^{\circ} \\
818\end{array}$ \\
\hline & Mixed forms & 0 & 10956 & 17397 & 25688 & 48793 \\
\hline & GRAND TOTAL & & 169122 & 169122 & 169122 & 169122 \\
\hline
\end{tabular}




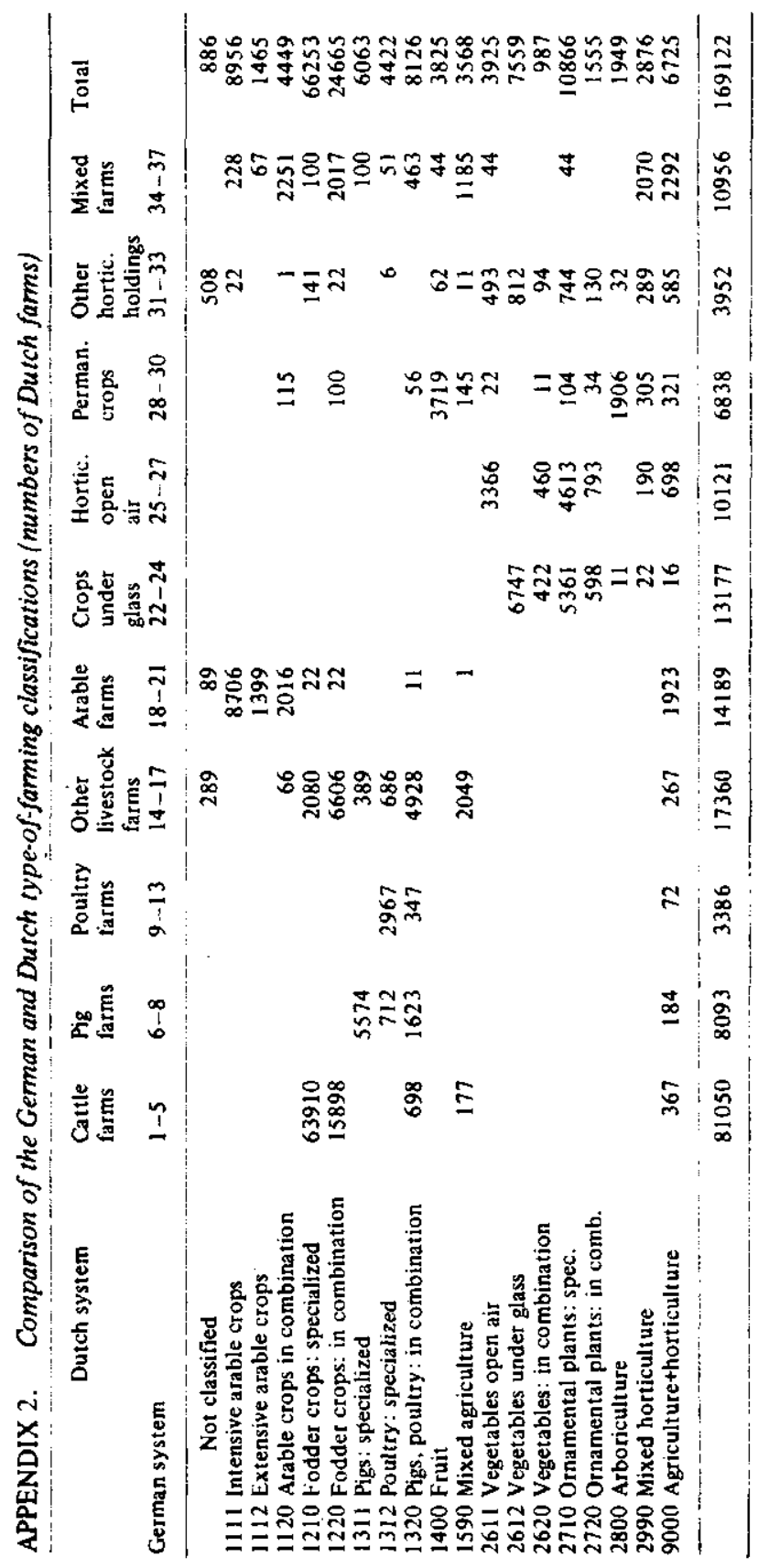




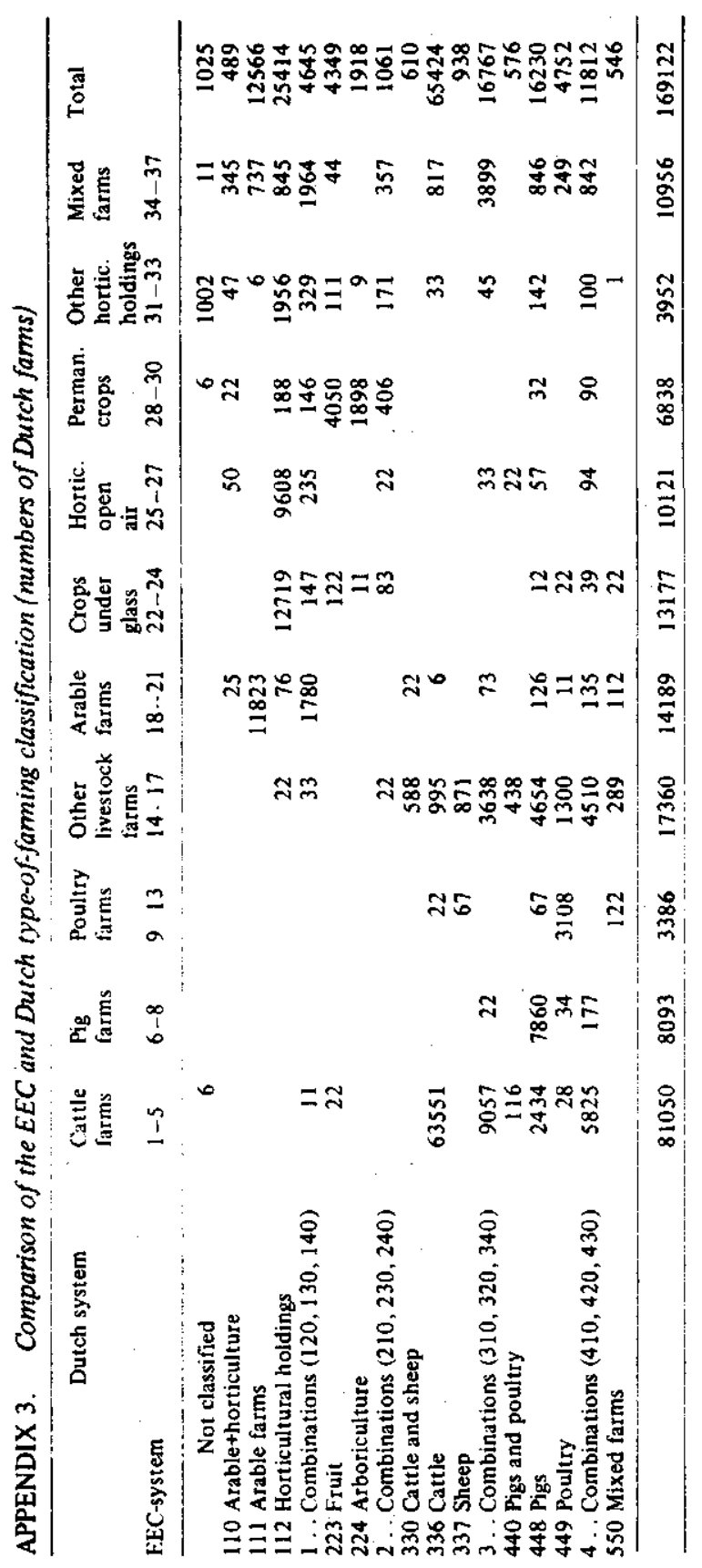




\section{REFERENCES}

Altena, L. van (1974) De indeling van landbouwbedrijven naar (hoofd) bedrijfstypen in 1968, 1971 en 1973. Bedrifssontwikke. ling, 5, 489-491. The Hague, Ministry of Agriculture and Food.

Centraal Bureau voor de Statistiek (1971) Agrarische bedrijfstypen op basis van standaardbedrijfseenheden mei 1968. The Hague, Staatsuitgeverij.

Deselaets, N. (1971) Neue Betriebssystematik für die Landwirtschaft. Berichte über Landwirtschaft, 49, 313-337. Mamburg and Berlin, Paul Parey.

Deselaers, N. (1974) New farm classification in the Federal Republic of Germany. European Review of Agricultural Economics, 1 (4), 447-460.
Furopean Commission (1966) Regulation no. 91/66/EEG of the Commission. Offical Journal of the European Communities. July, 2249-2266.

Wely, A. J. M. van (1961) Het tuinbouwbedrijf en het bedrijf met tuinbouw. Mededelingen van de Directeur van de Tuinbouw 1961. The Hague, Ministry of Agriculture and Food. Pp. 343-352, 423-429.

Wely, A. J. M. van, and Houten, G. A. van (1964) Agrarische Bedrijfsty'pen 1962. The Hague, Ministry of Agriculture and Food.

Wely, A. J. M. van, and Toolen, J. P. van ter (1968) Agrarische bedrijfstypen 1965. The Hague, Ministry of Agriculture and Food. 